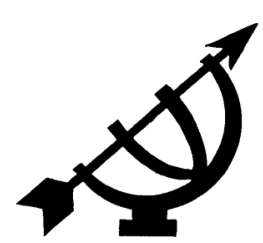

\title{
Head as metaphor in Paul ${ }^{1}$
}

\author{
A. Wolters \\ Religion \& Theology/Classical Languages \\ Redeemer College \\ Ancaster \\ CANADA \\ E-mail: awolters@quickclic.net
}

\section{Abstract \\ Head as metaphor in Paul}

Since the 1980s there has been a debate among New Testament scholars about the meaning of the Greek word "kephalē" ("head") in the Pauline epistles. Some scholars defend the traditional view that it means "leader", while others argue that it should be understood to mean "source". One result of this debate is that it is now clear that both the traditional and the new interpretation of kephale have very little support in general Greek usage before the New Testament.

This article seeks to advance the debate by showing that the phenomenon of "semantic borrowing" can explain why the meaning "source" is effectively limited to one passage in Herodotus, and the meaning "leader" is only found in Greek works written by bilingual Jews. The passage in Herodotus probably reflects a semantic loan from Old Persian *sar while various places in the Septuagint, Philo, Josephus and Paul reflect a semantic loan from Hebrew "ro'sh" (or Aramaic "re'sh"). Because the latter semantic loan ("head" meaning "leader") is embedded in the Greek Bible (both in the Septuagint and Paul), the authority and prestige of the latter can account for the fact that the new meaning of kephalē, though unknown in previous

$1 \quad$ I am pleased to be able to offer this essay as a token of my respect and affection for my long-time friend and colleague Elaine Botha, whom I have known since we were both graduate students in philosophy at the Vrije Universiteit in Amsterdam some forty years ago. Although I have since forsaken philosophy for biblical studies, I am aware of her excellent philosophical work on metaphor, and hope this contribution on a specific metaphor in the New Testament will be of interest to her, both professionally and personally. 
pagan Greek writings, gradually became widespread in postbiblical Greek as Christianity spread.

\section{Opsomming}

\section{Hoof as metafoor by Paulus}

Sedert die 1980s het daar onder Nuwe Testament-wetenskaplikes 'n debat gewoed oor die betekenis van die Griekse woord "kephale" ("hoof") in die sendbriewe van Paulus. Sommige wetenskaplikes verdedig die tradisionele siening dat dit "leier" beteken, terwyl ander argumenteer dat dit verstaan moet word as dat dit "bron" beteken. Een resultaat van hierdie debat is dat dit nou duidelik is dat daar vir sowel die tradisionele as die nuwe interpretasie van "kephalē" weinig ondersteuning te vind is in die algemene Griekse gebruik vóór die Nuwe Testament.

Hierdie artikel poog om die debat verder te voer deur aan te toon dat die fenomeen van "semantiese lening" kan verduidelik waarom die betekenis van "bron" effektief beperk is tot een passasie in Herodotus en die betekenis van "leier" slegs gevind word in Griekse werke wat geskryf is deur tweetalige Jode. Die passasie in Herodotus reflekteer waarskynlik 'n semantiese lening van die Oud-Persiese *sar, terwyl verskeie plekke in die Septuagint, Philo, Josephus en Paulus 'n semantiese lening van die Hebreeuse "ro'sh" (of Aramese "re'sh") reflekteer. Aangesien laasgenoemde semantiese lening ("hoof", wat "leier" beteken) in die Griekse Bybel ingebed is (sowel in die Septuagint as in Paulus), kan laasgenoemde se outoriteit en prestige verklaar word deur die feit dat die nuwe betekenis van "kephale", alhoewel onbekend in voorafgaande heidense Griekse geskrifte, geleidelik wydverspreid geraak het in die postBybelse Grieks, soos wat die Christendom versprei het.

\section{Introduction: state of the question}

Since the 1980s there has been a vigorous discussion among biblical scholars about the meaning of the Greek word kephale in certain key passages in the New Testament, especially those which speak of Christ as "head" of the church and the husband as "head" of his wife. The traditional assumption, reflected in virtually all New Testament versions and dictionaries of New Testament Greek, namely that headship in these contexts refers primarily to an authority relationship, has been challenged by a number of exegetes. They have based their arguments mainly on an earlier article by Bedale (1954) and on the kephalē entry in the Greek lexicon of Liddell et al. (LSJ, 1996), which does not list the meaning of "head" in the sense of "chief" or "leader." Instead, they have argued, the translation "source," which LSJ (1996) does list, is the appropriate 
rendering of kephalē in the passages in question. Leading proponents of this new view were Scroggs (1972), Murphy-O'Connor (1980), Mickelsen and Mickelsen (1986), and Kroeger (1987; 1993). The new interpretation has in turn been challenged by Grudem (1985) in an extensive study, and again (independently of Grudem) by Fitzmyer (1989). Thereafter an extensive reply to both Grudem and Fitzmyer was published by Cervin (1989). Subsequently both Grudem (1990; 2001) and Fitzmyer (1993) published further studies in defence of the traditional understanding of kephalē.

Although the meaning of kephale is still a matter of dispute, the dust of the earlier acrimonious debate seems to have settled somewhat. In retrospect, it is worth noting that the discussion has borne some significant fruit. It is now being acknowledged on all sides that both the traditional and the new interpretation of kephale has very little evidence to support it in extrabiblical Greek. The meaning "source" is very rare in extant Greek literature, but so is the meaning "chief" or "leader". To be sure, there are a few passages which can be plausibly argued to use kephalē in one of the two senses that have been advocated, but they constitute a small number, and are often so disputable that no firm conclusion can be drawn from them.

\section{The relevance of semantic borrowing}

In the hope of advancing the discussion a bit further, I would like to look, in this article, at the phenomenon of semantic borrowing as a key factor in the use of kephalē in these otherwise poorly attested senses. I shall argue that virtually every case of the meaning "source" and "leader" can be explained as the result of borrowing a meaning of the word for "head" in another language.

Semantic borrowing occurs when a meaning carried by a word in one language is transferred to a word in another language with which it is partially synonymous. Thus, in the French spoken in Canada, the verb introduire has borrowed the meaning "to cause to be acquainted" from the English verb "to introduce", which was not formerly a meaning of the French word. 2 This often happens inadvertently when people are speaking or writing a language which they know imperfectly. Thus, a native speaker of French may use the English word "deception" to mean "disappointment" by mistake, since that is a common sense of its French counterpart déception.

2 On the general concept of "semantic borrowing", see Silva (1975-1976:104-110; 1983:86-94; cf. also Hill, 1967). 
This kind of semantic interference is common in situations where two languages are widely used together by the same speakers.

\section{Kephale meaning "source" in Herodotus}

An indisputable case of kephale in the sense of "source" is found in Herodotus 4.91, where we find the story of the Persian king Darius stopping at the 38 springs (pēgai) which constituted the source of the river Tearus in Thrace. Darius was so impressed with the curative waters which these springs produced that he erected an inscribed stele on the spot to commemorate his passage. According to Herodotus (1972:244) the inscription reads as follows:

The springs of the Tearus (Tearou potamou kephalai) whose water is the finest in action and noblest in appearance of all rivers, was visited in the course of his march against Scythia by Darius son of Hystaspes, finest in action and noblest in appearance of all men, King of Persia and the whole continent.

As Cervin (1989:90) points out, there can be no doubt that kephalai here refers to the 38 springs which Herodotus had previously referred to as pēgai. Grudem's (1985:44; 1990:14-15) argument that kephalai in this context simply means "end points" must be rejected. The plural is easily accounted for by the reference to 38 springs, and the Greek text explicitly states that these kephalai "produce water" (hydōr ... parechontai). As far as I know, there is universal agreement among Herodotus translators and commentators that kephalai in this passage means "springs" or "sources".

Nevertheless, there is something distinctly odd about this usage. The ordinary Greek word for "spring" or "source" is pēgē or krēnē, and we have seen that Herodotus himself uses the former word to describe the springs of the Tearus. Furthermore, as Grudem (1985: 43) points out, the word kephale when used with reference to rivers elsewhere, means its mouth, not its source. There is some reason to believe that kephalē is here being used in a distinctive sense which is unusual in Greek.

In the light of this it is significant that the words which Herodotus quotes are undoubtedly a translation from Persian. Even on the unlikely assumption that the text on the stele was written in Greek, it would have been a translation of the wording which had been suggested or approved by Darius himself, whose language was Persian. It is much more likely, however, that the inscription itself was written in Persian, and that Herodotus is quoting a Greek trans- 
lation of the Persian inscription. According to one commentator on this passage (Herodotus, 1954-1966:4.104, note 1), "the inscription was undoubtedly engraved in cuneiform characters; Herodotus was given only a rough translation of it." 3 As a matter of fact, there is some evidence that the original stele, inscribed in the cuneiform script with which Old Persian was written, was still in existence near the source of the Tearus (present day Pinarhisar) in the early nineteenth century (Jochmus, 1854:44; Unger. 1915:6-9). Herodotus (Historiae 4.87) records that Darius erected at least one other stele with a cuneiform inscription during his European expedition against the Scythians, so that it is altogether likely that the inscription mentioning what Herodotus calls the kephalai of the Tearus, was also written in Persian.

Our knowledge of the Persian spoken by Darius, is very limited. The extant inscriptions in Old Persian contain only a few hundred nouns, and the word for "head" is not among them (cf. Kent, 1953:164-215). However, it must have been an ancestor of the modern Persian or Farsi word for "head", namely sar (Steingass, 1970:664a), ${ }^{4}$ which in the combination sar-āb, means "fountain-head" (Steingass, 1970: 667b). This expression is composed of the elements sar, "head," and $\bar{a} b$, "water, river" (Steingass, 1970:1a) and therefore means literally "head of water" or "head of river". A word for word translation of the latter into Greek would be kephale potamou, and the Persian for "the fountain-heads of the Tearus", if translated without regard to Greek idiom, would yield Tearou potamou kephalai. Since this is in fact the wording found in the inscription as quoted by Herodotus, it is probable that the unusual sense of kephalai reflects Persian usage. In short, kephalē meaning "source" is probably a semantic loan from Persian.

If this is admitted, it is no longer surprising that it is so hard to find parallels in Greek literature for kephalē meaning "source". An isolated Persianism in Herodotus is not likely to have been influential in broader Greek usage. Other examples of the meaning "source" are

3 As Legrand states (Herodotus, 1954-1966:4.104, note 1): “L'inscription était sans doute gravée en cunéiformes; il n'en fut donné à Hérodote qu'une traduction inexacte."

4 That the Old Persian word for "head" must have been an ancestor of sar is indicated by the fact that closely related Iranian languages in antiquity have cognates of sar as their word for "head". Thus the relevant word in Avestan is sarah- and in Pahlavi sar. On the former, see Bartholomae (1904:1572) and on the latter, see MacKenzie (1971:74). 
at best arguable, and at worst far-fetched. 5 The strongest case can be made for the Orphic Fragment 21a (cf. LSJ, 1996 under kephale II, d), since Zeus, the cosmic creator in Orphism, is there described as the kephale (or archē) of all things. But of course the meaning "beginning" is also possible (cf. Grudem, 1985:45; 1990:16). Guthrie, a leading authority on Orphism, quotes this line to the effect that the Orphic Zeus is "beginning, middle and end of all" (Guthrie, 1966:82). Without the precedent of the Herodotus passage, it is unlikely that the meaning "source" would have been proposed for kephalē/archē in this Orphic fragment. In fact, the lexical support for the meaning "source" for classical Greek kephalē seems to consist almost entirely of this single case of what appears to be a semantic loan in Herodotus.

\section{Kepha/e associated with leadership in pagan Greek}

We turn now to another meaning of kephale which was rare in classical Greek, namely "chief" or "leader". This metaphorical meaning of the word for "head" is so common in other languages (as well as later Greek), that it comes as a surprise to discover that it is virtually unattested in pagan Greek literature until about the fourth century AD. It is true that Grudem and Fitzmyer have collected an impressive number of places in extrabiblical Greek where kephalē is associated with leadership and authority, but there are actually very few cases where the word itself actually means something like "chief" or "leader". These few cases are all found (until the fourth century AD.) in the writings of Jews and Christians. It will be necessary, therefore, to define more precisely under what circumstances kephalē can be said to have the lexical meaning "leader" or the like, and to deal separately with pagan as opposed to Judeo-Christian writings. As we shall see, the pervasive influence of the Hebrew Scriptures, and the associated presence of semantic borrowing from Hebrew and Aramaic, are key factors in understanding the Greek usage of the latter category, but have no relevance for the former.

In considering the passages in Greek literature which Grudem and Fitzmyer have collected to show that kephale did have associations with leadership and authority, it is necessary to distinguish between the following four categories: firstly, instances where the physical head is said to rule or lead other parts of the body; secondly, where

$5 \quad$ Fitzmyer (1993:53-54) allows six examples besides the one in Herodotus. For a particularly far-fetched example, see the use of kephale in Artemidorus Daldianus, Oneirocriticon 1.2, 1.35 and 3.66 (cf. Cervin, 1989:92-94). 
a leader is compared to the physical head; thirdly, where a leader is symbolised by the physical head; and fourthly, where a leader is actually called the "head" of something else. In the lexical sense of "meaning" it is only in the last case that we can say that "head" means "leader" and could be appropriately translated as such. 6

If we look at the usage of kephalē in pagan Greek literature with these distinctions in mind, it is striking that there does not appear to be a single instance where the word has the lexical meaning "chief" or "leader". There are examples of usage number 1, according to which the physical head is said to rule over the body (Plato Timaeus 44d) or to constitute a ruling part of the human being (Plutarch Moralia 692D). There are also a number of instances of usage number 2 (all found in Plutarch), in which a human leader (the commander of an army, Catiline, Galba, or a leader in general) is compared to the head of a body (Plutarch Pelopidas 2.1; Cicero 14.4; Galba 4.3; Agis et Cleomenes 2.3), but the leader himself is never actually called a kephale. Finally, there is one example of usage number 3, found in an enigmatic Delphic oracle recorded in Herodotus, where kephalē probably symbolises the ruling class of the Greek city Argos (Herodotus Historiae 7.148). Nowhere, however, do we find an example of usage number 4 . As far as pagan Greek literature is concerned, LSJ (1996) is entirely justified in omitting the meaning "chief" or "leader" from its entry on kephalē.

\section{Kephale meaning "leader" in Jewish Greek}

The situation is different, however, when we come to the Greek literature which was influenced by the Hebrew Bible. Here we can observe the gradual encroachment of the meaning "chief" or "leader", which is a common sense of the Hebrew word for "head", namely ro'sh. This can be illustrated by examining the evidence in chronological order: first the Septuagint and the Jewish writers Philo and Josephus, and then the New Testament and other early Christian literature.

6 See the excellent discussion in Cotterell and Turner (1989:141-45). In distinguishing between the different ways in which kephale was associated with leadership and authority in pagan Greek literature, I am not claiming that some of these ways are metaphorical and others not. My point is to distinguish lexical meaning (the fourth category) from the other three usages. It is only in this usage that kephalē can be appropriately translated as "chief" or "leader". 


\subsection{Septuagint}

The evidence of the Septuagint shows clearly that ordinary Greek usage resists the meaning "leader" for kephalē. Although the Hebrew word ro'sh in the sense of "leader" occurs some 180 times in the Old Testament, the Septuagint generally avoids translating it as kephalē in those cases. Instead, it tends to use words like archōn, "ruler", and archēgos, "leader" to convey this meaning (Mickelsen \& Mickelsen, 1986:101-104). However, there are also a number of exceptions to this general trend, where the translators use kephalē, against normal Greek usage, to express the meaning "leader". A clear example is found in the story of Jephtha in Judges 11:11, where we read of Jephtha that "the elders of Gilead and the people made him head and commander over them". Here the word "head" (Hebrew ro'sh) is translated as kephale in the Septuagint, even though it clearly means "leader", and the Greek word does not normally have that meaning. ${ }^{7}$ In other words, this is an example of semantic borrowing, where the Greek word for "head" is used to convey one of the meanings of the Hebrew word for "head".

Although this use of kephalē meaning "leader", is not common in the Septuagint, it is not rare either. Scholars disagree as to the exact number of instances of this usage, with estimates ranging from eight (cf. Mickelsen \& Mickelsen, 1986:104; Fitzmyer, 1993:55) to thirteen (Grudem, 1985:54-55). Whatever the exact number, it is clear that a semantic precedent had been set. There is in fact no dispute about the fact that in the Septuagint the word kephale does sometimes have the meaning "he who or that which plays a leading role" (Muraoka, 2009:396b).

\subsection{Philo and Josephus}

The trend that had been begun by the Septuagint was continued by Philo and Josephus. In the case of Philo, who was influenced as much by pagan Greek literature (especially Plato) as by the Greek Bible, it is not surprising that we find places in his writings where he speaks of the physical head ruling the body (De specialibus legibus 3.184), of human leadership compared to the head (De praemiis et poenis 114), and human leadership symbolised by the head (De somniis 2.207). As noted above, these usages are also found in

$7 \quad$ This is true of both recensions (A and B) of the Septuagint of Judges (cf. Rahlfs \& Hanhart, 2006:1.453). The A recension also uses kephale for ro'sh in verses 8 and 9 , whereas the $\mathrm{B}$ recension has archōn in those verses. 
pagan Greek literature. What is striking about Philo, however, is that he also exemplifies what we have called usage number 4 , where something or someone is actually called the kephale of something else. He calls the mind "the kephalē and ruling part of sense-perception" (De vita Mosis 2.82), designates Ptolemy Philadelphos as the "kephalē, in a way, of the (Ptolemaic) kings" (De vita Mosis 2.30 ), and speaks of the virtuous man or nation as the "kephale of the human race" (De praemiis et poenis 125). Since this usage has no parallel in earlier Greek literature, it is reasonable to assume that it represents a semantic loan like the one we noticed in the Septuagint, especially since Philo was intimately acquainted with the Septuagint.

The writings of Philo's younger contemporary, Josephus, contain one example each of usage number 2 and number 4 , both found in The Jewish War. In the first example he compares the sovereignty of the capital Jerusalem over Judea to that of the head over the body (3.3.5 [\#54]), and in the second example he designates Jerusalem directly as the "kephalē of the entire nation" (4.4.3[\#261]). Again, it is very probable that this last example represents a semantic loan, in this case not because of the influence of the Septuagint, but because Josephus originally wrote his Bellum Judaicum in Aramaic (Feldman, 1984:838), ${ }^{8}$ and Aramaic re'sh (like its Hebrew cognate ro'sh) commonly means "leader" (Sokoloff, 1990:510b).

\subsection{Paul}

With this as background we turn to another Greek-speaking Jew of the first century, namely Paul of Tarsus, who like Philo was intimately acquainted with the Septuagint, and like Josephus knew both Hebrew and Aramaic. In three of his letters he speaks of Christ as kephalē - usually in relation to the church (Eph. 1:22; 5:23; Col. $1: 18 ; 2: 19$ ), but also in relation to every man or husband (1 Cor. $11: 3$ ), to "all rule and authority" (Col. 2:10), and over "all things" (Eph. 1:22). On three occasions he also speaks of the husband as kephale of the wife (1 Cor. 11:3, 5; Eph. 5:23), and on another of God as kephalē of Christ (1 Cor. 11:3). It is on these texts that we find the advocates of the meaning "source" pitted against the advocates of the meaning "leader".

8 As Feldman points out, some have argued that Josephus wrote the Jewish War in Hebrew, not Aramaic. This, however, would make no difference to the point we are making. 
In the light of the discussion so far, it is clear that Paul is using kephalē in a sense which is unusual in ordinary Greek, and would probably have sounded unidiomatic to his Greek-speaking contemporaries, especially those unacquainted with the Septuagint. However, the context is sufficiently clear in most cases to allow the reader to understand that when Paul calls Christ the kephale of the church, of "all rule and authority", or "over all things", he is stressing the sovereignty and pre-eminience of Christ with respect to these matters. This is particularly clear when kephale is associated with the language of subjection or subordination, as in Ephesians 5:2224:

Wives be subject to your husbands, as you are to the Lord. For the husband is the head [kephalē] of the wife as Christ is the head [kephalē] of the church, the body of which he is the Savior. As the church is subject to Christ, so also wives ought to be, in everything, to their husbands. (NRSV.)

It is true that this passage occurs in the context of a general call to mutual submission, but at least with respect to Christ's headship, it is clear that headship involves unilateral authority. This impression would have been reinforced for Paul's readers by the well documented association in Greek literature of kephale and leadership, and, in the case of his Jewish readers, by the instances of semantic borrowing based on ro'sh and re'sh which appear in the Septuagint and in Philo and Josephus. Paul's usage is certainly bold, but it stands in continuity with the developments which have been sketched.

At the same time, there are at least two passages which clearly suggest that Christ as kephale is the source of the church's growth. This is explicitly indicated by the words ex hou ("from whom"), referring to Christ as head, which are found in Ephesians 4:15 and Colossians 2:19. We find a similar point made in connection with husband and wife in 1 Corinthians 11:8 (gunē ex andros), in a context that speaks of the husband as kephale of the wife. The association of kephalē with the source imagery is rather startling, since the physical head is never the source of the rest of the body in ordinary experience. Moreover, the idea of growing out of Christ as head is combined with that of growing into him in Ephesians 4:15. To the best of my knowledge, there are no parallels to this image of the head as source (and goal) of the body's growth in all of Greek literature. As indicated, the meaning "source" for kephale is clearly attested only in the Tearus passage in Herodotus, and has nothing to do with the idea of a body growing out of a head. Nor am I aware 
of any parallel in Hebrew or Aramaic writings. It seems that there is no precedent at all for this striking Pauline image.

\section{Kepha/ē meaning "source" in two Jewish Pseud- epigrapha?}

At this point it will be useful to look at two passages in JewishChristian pseudepigraphical writings in which kephalē is used in an unusual sense that may have a bearing on Paul's association of "head" and "source". The first is found in The Testament of Reuben, part of The Testaments of the Twelve Patriarchs, and reads as follows in the translation of Hollander and De Jonge (1985:91; for the Greek text, cf. De Jonge, 1970:2):

And now listen to me, children, what I saw concerning the seven spirits of deceit when I repented. Seven spirits were given by Beliar against man and they are the head [kephalē] of the works of the behavior of youth.

Is this an example of kephale being used in the sense of "source", as suggested by Cervin (1989:99) and Fitzmyer (1993:54)? Based on the immediate context, one might be inclined to think so. However, Hollander and De Jonge (1985:93), in their note on this passage, state that kephale should be understood "as 'chief' or 'leader'”. Furthermore, Charles (1913:297) saw the word as reflecting an underlying Hebrew ro'sh, and, therefore, also translated it as "leaders". In other words, he understood kephale to be another example of a semantic loan from Hebrew. In any case, other translators of The Testament of Reuben give a variety of renderings of kephale in this passage, but "source" is not among them. ${ }^{9}$

The second pseudepigraphical passage which may be relevant for our discussion, is found in the Greek version of The Life of Adam and Eve, also known as the Apocalypse of Moses. In Eve's account of the serpent in the garden and the eating of the forbidden fruit, many editions include the following sentence at 19.3:

Then the serpent went, and on the fruit which he gave me to eat he put the venom of his wickedness, that is desire - for desire is the kephalē of every sin (Bertrand, 1987:84; translation of the Greek by AW.)

$9 \quad$ See Becker (1974:33; Oberhaupt), Piñero (1987:30; los causantes), DupontSommer and Philonenko (1987:818; les responsables). 
In this context kephale has been translated as Anfang (cf. Fuchs, 1900:2.521), principe (cf. Bertrand, 1987:85), and "origin" (cf. Johnson, 1983-1985, 2:279). We might also translate kephalē as "root", since it is a commonplace in Rabbinic literature that desire is at the root of all sin. In fact, one manuscript actually has the reading riza kai archē ("root and beginning") instead of kephalē (cf. the critical apparatus in Bertrand, 1987:84). It can be argued that this is in the neighbourhood of the meaning of "source".

However, there are two reasons why we should be cautious in giving this evidence of the meaning "source" any great weight. First of all, the word kephalē is found in only some manuscripts of the work, and may not be part of the original text at all. In fact, it has disappeared from the text in the recent critical edition by Tromp (2005:142). Secondly, if it was part of the original text, there is good reason to believe that the Greek is the translation of a Hebrew original and that kephale reflects a wordplay in the Hebrew. It can hardly be a coincidence that ro'sh in biblical Hebrew also means "venom," specifically of snakes (Brown et al., 1906:912b). In the Hebrew Vorlage, the ro'sh which the serpent puts on the forbidden fruit is also the ro'sh of every sin. Once we realise that a play on Hebrew ro'sh is involved, it becomes clear that "the ro'sh of every sin" probably means its beginning, since this is a well-attested sense of the Hebrew word (Brown et al., 1906:911a). In the light of this underlying Hebrew wordplay, kephale in this passage is best understood as "beginning" rather than "source".

Our conclusion with respect to the use of kephale in The Testament of Reuben 2.2 and The life of Adam and Eve 19.3 is therefore that it does little or nothing to alleviate the strangeness of the apostle's image of the head as source of the body's growth. Although semantic borrowing in previous Jewish Greek usage can be said to account in large measure for Paul's use of kephalē in contexts suggesting an authority relationship, there appear to be no comparable precedents for his association of kephale with the source image.

\section{Kephaß̄e meaning "leader" after Paul}

If we are right in concluding that the semantic loan where kephale means "chief" or "leader" was significantly represented in both the Septuagint and the New Testament, it is reasonable to expect that this usage would also leave its mark on the language of Greekspeaking Christians in the subsequent centuries of the Christian era, since it was precisely these two collections which now constituted the Holy Scriptures of the Early Church. Like Luther's Bible for 
German and the King James Version for English, the Greek Bible was a powerful molding force for the Greek language, as the Christian religion spread and gained in prestige. It is not surprising therefore to find that kephalē in the meaning of "chief" or "leader", which was unknown in pagan Greek and only sporadically represented in Jewish Greek, becomes common in patristic Greek and from there enters the vocabulary of pagan Greek authors by the fourth century. Thereafter, in Byzantine and Modern Greek, the usage is firmly established as part of the ordinary semantic structure of the language.

We see a clear example of this beginning of the overall development as early as the second century in the Similitudes of the Shepherd of Hermas, where a person is addressed as kephale tou oikou, "head of the household" (7.3), which clearly means the person in charge. Further examples from patristic literature are easy to find, as a glance at the entry on kephalē in the Patristic Greek Lexicon will confirm (Lampe, 1961:748).

In the fourth century the meaning of "chief" or "leader" for kephalē is sufficiently established for Libanius, a famous pagan rhetor, to be able to make a pun in one of his speeches which depends on this usage. He says of rioters in Antioch, who were reviling the political authorities during the famous incident about the statues, that they were actually heaping insults "upon their heads" (Libanius, 1977: 312). He meant that the insults directed against the authorities actually reflected on the rioters. A scholion in one of the manuscripts of this passage notes: "by 'heads' here he means the rulers themselves", to make sure that the double entendre would not be missed (Libanius, 1977:313, note). That such a wordplay was possible would seem to demonstrate that in the time of Libanius the relevant usage of kephale would have been understood by a pagan audience.

It is not necessary to document the widespread use of kephale in its new sense in Byzantine and Modern Greek, because it is well attested in the relevant dictionaries (Du Cange, 1958, Sophocles, 1870; Pring, 1965; cf. Kazhdan, 1991:1122). It is ordinary usage to speak of the commander-in-chief of the army as its "head", or of the president of the republic as the "head" of state. There is no longer anything strange or unusual about such expressions in the Greek language.

It would seem that the semantic loan which first occurred sporadically in the Septuagint, and then in a few key passages in the New 
Testament, proved to be enormously influential because of the authority of the Bible. Although the semantic development which has been sketched may have been aided by the influence of Latin, since caput also frequently refers to authority, it is undoubtedly the semantic loan enshrined in Holy Writ that was mainly responsible for it.

\section{Kephaאe in Paul: "superior rank" and source imagery}

A final word about the disputed passages in the New Testament. In the light of the overall semantic history of kephalē, as well as the exegesis of the Greek church fathers, it is clear that Paul's usage of kephale can be interpreted as an important link in the progressive popularisation of a semantic loan based on Hebrew ro'sh. Paul's striking assertion of Christ as kephale (his use of the same term for God and husbands are subsidiary to this) throws into bold relief a Hebraistic usage which was unknown in pagan Greek and incidental in Jewish Greek. At the same time it gives a fresh impetus for the propagation of this usage through the spread of the Greek-speaking church. This continuity of development underscores the legitimacy of the standard interpretation of kephalè as denoting "superior rank" (Bauer, 1979:430a).

However, it does not shed light on Paul's association of kephalē with the source metaphor. There is no comparable line of semantic development which would link Paul's usage to earlier and later examples of kephalē meaning "source". The gap separating the isolated case in Herodotus from the New Testament is simply too great. Postbiblical Greek, to the best of my knowledge, shows virtually no sign of this meaning for kephale. This is not to deny that the source metaphor is present in Paul; it is simply to state that it is a metaphor which has virtually no support in the lexical meaning of kephale elsewhere, and must be explained (if it can be explained) in some other way. Although there is no reason why the recognition of source imagery cannot coexist with the traditional interpretation of kephale in Paul (Ridderbos, 1975:380-381), there can be little doubt that on the lexical level, it is the semantic borrowing based on Hebrew ro'sh and not on Persian *sar, which provides the key to Paul's usage.

\section{List of references}

BARTHOLOMAE, C. 1904. Altiranisches Wörterbuch. Strassburg: Trübner.

BAUER, W. 1979. A Greek-English Lexicon of the New Testament and Other Early Christian Literature. Trans. and revised by W.F. Arndt, F.W. Gingrich \& F.W. Danker. Chicago: University of Chicago Press. 
BECKER, J. 1974. Die Testamente der zwölf Patriarchen: Jüdische Schriften aus hellenistisch-römischer Zeit: Band 3. Unterweisung in lehrhafter Form. Gütersloh: Mohn.

BEDALE, S. 1954. The meaning of kephalē in the Pauline epistles. Journal of theological studies, 5:211-215.

BERTRAND, A. 1987. La vie grecque d'Adam et Ève: introduction, texte, traduction et commentaire. Paris: Maisonneuve. (Recherches Intertestamentaires, 1.)

BROWN, F., DRIVER, S.R. \& BRIGGS, C.A. 1906. A Hebrew and English Lexicon of the Old Testament. Oxford: Clarendon.

CERVIN, R.S. 1989. Does kephalē mean "source" or "authority over" in Greek literature? A rebuttal. Trinity journal, 10:85-112.

CHARLES, R.H. 1913. The apocrypha and pseudepigrapha of the Old Testament in English. Vol. 2: Pseudepigrapha. Oxford: Clarendon.

COTTERELL, P. \& TURNER, M. 1989. Linguistics and biblical interpretation. Downers Grove: InterVarsity.

DE JONGE, M. 1970. Testamenta XII patriarcharum. Leiden: Brill.

DU CANGE, C. 1958. Glossarium ad scriptores mediae et infimae graecitatis. Reprint Graz: Akademische Druck- und Verlagsanstalt.

DUPONT-SOMMER, A. \& PHILONENKO, M. 1987. La Bible: Écrits intertestamentaires. Paris: Gallimard.

FELDMAN, L.H. 1984. Flavius Josephus revisited: the man, his writings, and his significance. (In Temporini, H. \& Haase, W., Red. Aufstieg und Niedergang der römischen Welt II 21.2. Berlin: De Gruyter. p. 763-862.)

FITZMYER, J.A. 1989. Another look at kephale in 1 Corinthians 11:3. New Testament studies, 35:503-511.

FITZMYER, J.A. 1993. Kephalē in 1 Corinthians 11:3. Interpretation, 47:52-59.

FUCHS, C. 1900. Das Leben Adams und Evas. (In Kautzsch, E., Red. Die Apokryphen und Pseudepigraphen des Alten Testaments. 2 vols. Tubingen: Mohr. S. 506-28.)

GRUDEM, W. 1985. Does kephale ("head") mean "source" or "authority over" in Greek literature? A survey of 2,336 examples. Trinity journal, 6:38-59.

GRUDEM, W. 1990. The meaning of kephale ("head"): a response to recent studies. Trinity journal, 11:3-72.

GRUDEM, W. 2001. The meaning of kephalē ("head"): an evaluation of new evidence, real and alleged. Journal of the Evangelical Theological Society, 44:25-65.

GUTHRIE, W.K.C. 1966. Orpheus and Greek religion: a study of the Orphic movement. New York: Norton.

HERODOTUS. 1954-1966. Histoires, texte établi et traduit par Ph. E. Legrand. 10 vols. Paris: Belles Lettres.

HERODOTUS. 1972. The histories. New ed. Trans. by A. de Sélincourt; revised by J. Marincola. London: PenguinBooks.

HILL, D. 1967. Greek words and Hebrew meanings: studies in the semantics of soteriological terms. Cambridge: Cambridge University Press.

HOLLANDER, H.W. \& DE JONGE, M. 1985. The testaments of the twelve patriarchs: a commentary. Leiden: Brill.

JOCHMUS, A. 1854. Notes on a journey into the Balkan, or Mount Haemus, in 1847. The journal of the Royal Geographical Society, 24:38-85. 
JOHNSON, M.D. 1983-1985. The life of Adam and Eve. (In Charlesworth, J.H., ed. Old Testament pseudepigrapha. 2 vols. Garden City: Doubleday. p. 2.249-295.)

KAZHDAN, A.P. 1991. The Oxford Dictionary of Byzantium. 3 vols. New York: Oxford University Press.

KENT, R.G. 1953. Old Persian: grammar, texts, lexicon. 2nd rev. ed. New Haven: American Oriental Society.

KROEGER, C. 1987. The classical concept of "head" as "source." (In Gaebelein Hull, G., ed. Equal to serve: women and men working together revealing the gospel. Old Tappan: Revell. p. 267-283.)

KROEGER, C. 1993. Head. (In Hawthorne, G.F., ed. Dictionary of Paul and his letters. Downers Grove: InterVarsity. p. 375-377.)

LAMPE, G.W.H. 1961. A Patristic Greek Lexicon. Oxford: Clarendon.

LIBANIUS. 1977. Orations. Trans. by A.F. Norman. Cambridge: Harvard University Press. (Loeb Classical Library.)

LIDDELL, H.G., SCOTT, R. \& JONES, H.S. 1996. A Greek-English Lexicon. 9th ed. with rev. suppl. Oxford: Clarendon.

LSJ

see LIDDELL, H.G., SCOTT, R. \& JONES, H.S.

MACKENZIE, D.N. 1971. A Concise Pahlavi Dictionary. London: Oxford University Press.

MICKELSEN, B. \& MICKELSEN, A. 1986. What does kephalē mean in the New Testament? (In Mickelsen, A., ed. Women, authority and the Bible. Downers Grove: InterVarsity. p. 97-110.)

MURAOKA, T. 2009. A Greek-English lexicon of the Septuagint. Louvain: Peeters.

MURPHY-O'CONNOR, J. 1980. Sex and logic in 1 Corinthians 11:2-16. Catholic biblical quarterly, 42:482-500.

PIÑERO, A. 1987. Testamentos de los doce patriarcas. (In Díez-Macho, A., ed. Apócrifos del Antiguo Testamento. Tomo V. Testamentos o discorsos de adios. Madrid: Ediciones Cristiandad. p. 9-158.)

PRING, J.T. 1965. The Oxford Dictionary of Modern Greek (Greek-English). Oxford: Clarendon.

RAHLFS, A. \& HANHART, R. 2006. Septuaginta, id est Vetus Testamentum graece iuxta LXX interpretes edidit Alfred Rahlfs Editio altera quam recognovit et emendavit Robert Hanhart. Duo volumina in uno. Stuttgart: Deutsche Bibelgesellschaft.

RIDDERBOS, H. 1975. Paul: an outline of his theology. Trans. by J.R. de Witt. Grand Rapids: Eerdmans.

SCROGGS, R. 1972. Paul and the eschatological woman. Journal of the American Academy of Religion, 40:283-303.

SILVA, M. 1975-1976. Semantic borrowing in the New Testament. New Testament studies, 22:104-110.

SILVA, M. 1983. Biblical words and their meaning: an introduction to lexical semantics. Grand Rapids: Zondervan.

SOKOLOFF, M. 1990. A Dictionary of Jewish Palestinian Aramaic. Ramat-Gan: Bar Ilan University Press.

SOPHOCLES, E.A. 1870. Greek lexicon of the Roman and Byzantine periods (from BC 146 to AD 1100). Boston: Little \& Brown.

STEINGASS, F.A. 1970. A Comprehensive Persian-English Dictionary. Reprint. Beirut: Librairie du Liban. 
TROMP, J.. 2005. The life of Adam and Eve in Greek: a critical edition. Leiden: Brill.

UNGER, E. 1915. Die Dariusstele am Tearos: archäologischer Anzeiger. Beiblatt zum Jahrbuch des archäologischen Instituts, 30:3-17.

\section{Key concepts:}

Greek language

head

kephalē

Paul

semantic borrowing

Kernbegrippe:

Griekse taal

hoof

kephalē

Paulus

semantiese lening 
